\title{
Morbidity and 30-day mortality after decortication for parapneumonic empyema and pleural effusion among patients in the Society of Thoracic Surgeons' General Thoracic Surgery Database
}

Christopher W. Towe, MD, ${ }^{\mathrm{a}}$ Shamus R. Carr, MD ${ }^{\mathrm{b}}$ James M. Donahue, MD,${ }^{\mathrm{c}}$ Whitney M. Burrows, MD, ${ }^{\mathrm{b}}$ Yaron Perry, MD, ${ }^{\mathrm{a}}$ Sunghee Kim, PhD, ${ }^{\mathrm{d}}$ Andrzej Kosinski, $\mathrm{PhD},{ }^{\mathrm{d}}$ and Philip A. Linden, $\mathrm{MD}^{\mathrm{a}}$

\section{ABSTRACT}

Objective: We analyzed the Society of Thoracic Surgeons' Database to describe the results of surgical decortication.

Methods: A review of patients undergoing pulmonary decortication, excluding hemothorax and malignancy, from 2009 to 2016 was performed. Preoperative factors, length of stay, discharge status, readmission, morbidity, and mortality were compared between open and video-assisted thoracoscopic surgery approaches. Multivariable models identified risk factors for morbidity and mortality.

Results: Of 7316 patients undergoing decortication, 6961 (95.2\%) had a primary diagnosis of empyema. Video-assisted thoracoscopic surgery was used in 4435 patients $(60.6 \%)$ and increased during the study period. Median length of stay was 4 days (interquartile range, 2-7) preoperatively and 7 days (interquartile range, 5-11) postoperatively. Mortality occurred in 228 patients (3.1\%). Complications occurred in 2875 patients (39.3\%), and major morbidity occurred in 1138 patients $(15.6 \%)$. Transitional care after discharge occurred in 1922 patients $(26.3 \%)$. Readmission within 30 days occurred in 452 patients ( $8.7 \%$ ). Compared with video-assisted thoracoscopic surgery, mortality, major morbidity, prolonged length of stay, and discharge to other than home were higher with thoracotomy. In multivariable analysis, age, estimated glomerular filtration rate less than 60, chronic obstructive pulmonary disease, body mass index, American Society of Anesthesiologists level, Zubrod score, and thoracotomy were associated with increased mortality, morbidity, discharge to transitional care, and prolonged length of stay. Each additional preoperative hospital day (up to 5 days) increased mortality. Readmission, major morbidity, prolonged length of stay, and discharge to transitional care were all higher when preoperative hospitalization extended

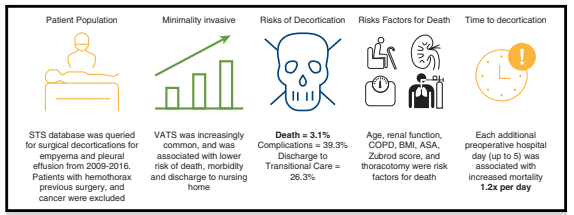

Visual summary of the article.

\section{Central Message}

Decortication for parapneumonic empyema is performed with substantial morbidity. Several factors, including increased time between admission and operative intervention, are associated with poor outcomes.

\section{Perspective}

We report outcomes of decortication from the Society of Thoracic Surgeons' Database. Poor functional status and renal function were predictors of adverse outcome, whereas VATS was associated with reduced death and complications. Delay in surgical intervention was also associated with poor outcomes. These data highlight the risk of decortication and suggest future research into timing of decortication.

See Commentaries on pages 1298 and 1300 . beyond 5 days.

Conclusions: Surgeons participating in the Society of Thoracic Surgeons General Thoracic Surgery Database perform decortication for parapneumonic empyema and pleural effusion with limited mortality despite substantial postoperative morbidity. Further study is required to describe selection criteria for video-assisted thoracoscopic surgery and determine indications for surgical intervention to reduce delays in operative intervention. (J Thorac Cardiovasc Surg 2019;157:1288-97)

\footnotetext{
From the ${ }^{\mathrm{a}}$ Division of Thoracic and Esophageal Surgery, Department of Surgery, University Hospitals Cleveland Medical Center and Case Western Reserve School of

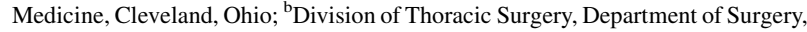
University of Maryland School of Medicine, Baltimore, Md; ' Division of Cardiothoracic Surgery, Department of Surgery, University of Alabama at Birmingham School of Medicine, Birmingham, Ala; and ${ }^{\mathrm{d}}$ Duke Clinical Research Institute, Durham, NC.

C.W.T. and S.R.C. are co-first authors
}

Received for publication April 3, 2018; revisions received Aug 3, 2018; accepted for publication Oct 12, 2018.

Address for reprints: Christopher W. Towe, MD, Division of Thoracic and Esophageal Surgery, University Hospitals Cleveland Medical Center, 11100 Euclid Ave, Cleveland OH 44106-5011 (E-mail: christopher.towe@uhhospitals.org). $0022-5223 / \$ 36.00$

Copyright (C) 2018 by The American Association for Thoracic Surgery https://doi.org/10.1016/j.jtcvs.2018.10.157 


\section{Abbreviations and Acronyms \\ ASA $=$ American Society of \\ Anesthesiologists \\ BMI = body mass index \\ COPD $=$ chronic obstructive pulmonary disease \\ CPT = Current Procedural Terminology \\ DVT $=$ deep venous thrombosis \\ eGFR = estimate glomerular filtration rate \\ IQR = interquartile range \\ LOS = length of stay \\ OR $\quad=$ operating room \\ PLOS $=$ prolonged length of stay \\ STS-GTSD $=$ the Society of Thoracic Surgeons General Thoracic Surgery Database \\ VATS = video-assisted thoracoscopic surgery}

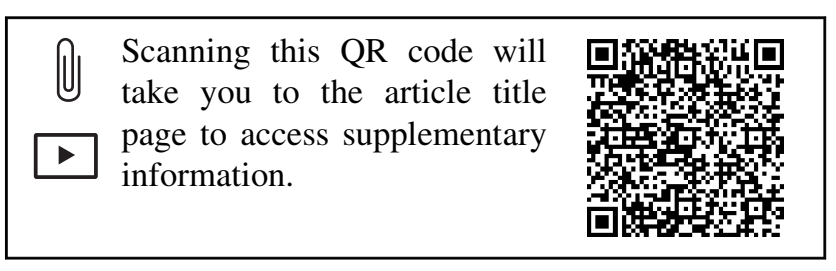

Empyema can lead to significant morbidity if not appropriately treated. In the United States, hospitalizations for empyema increased from 3.04 per 100,000 in 1996 to 5.98 per 100,000 in 2008. ${ }^{1}$ Data from the Health Care Utilization Project demonstrate the number of hospitalizations for empyema with or without fistula in 2013 was approximately 45,000 , occurring twice as frequently as it did 20 years prior. $^{2}$

Many patients with empyema are treated with surgical decortication, and some studies suggest poor outcomes after surgery, with mortality rates of up to $9 \% .^{3-5}$ Results of decortication for empyema come mainly from single institution retrospective studies. These studies are heterogeneous and difficult to compare because of the complex nature of the disease and the varying patient population. For example, the need to convert from video-assisted thoracoscopic surgery (VATS) to thoracotomy has varied from $8 \%$ to $59 \%$ in recent reports. ${ }^{6,7}$ Reports of postoperative complications are also inconsistent. Operative mortality ranges from zero to $9.0 \% .{ }^{5,8}$ Inconsistencies also exist with respect to the reported risk factors associated with poor outcomes after surgery. A study from Schweigert and colleagues ${ }^{4}$ reported on the association of Charlson comorbidity score and American Society of Anesthesiologists (ASA) with perioperative mortality. ${ }^{4}$ In this study, the investigators found no association of elderly age and poor outcome. However, older age was strongly correlated with perioperative mortality in a larger study by Mikkola and colleagues. ${ }^{3}$

To date, there here have been no large, multiinstitutional studies of outcome after decortication for empyema and complex pleural effusion. We performed an analysis of the Society of Thoracic Surgeons' General Thoracic Surgery Database (STS-GTSD) to assess clinical outcomes for patients who underwent surgical decortication for acute empyema and parapneumonic pleural effusion. Because these conditions represent the most common indications for decortication, we chose to focus our analysis, within the limitations of the database, on these patients. To do so, we excluded patients undergoing decortication for less common indications, such as traumatic hemothorax, malignancy, esophageal perforation, and postoperative complications. With this cohort, we used univariate and multivariable analyses to determine risk factors for poor outcomes.

\section{MATERIALS AND METHODS}

\section{Society of Thoracic Surgeons' Database}

The STS-GTSD was established to support research into surgical outcome after thoracic surgery. Details of the STS data collection, reporting, and data definitions are available at www.sts.org. ${ }^{9}$ The Duke University Institutional Review Board approved this study as exempt from Institutional Review Board review before data analysis. The Society of Thoracic Surgeons' National Database Access and Publications Research Program provided the access to data and the analytics support required for this research.

\section{Patient Population}

The study population consisted of all patients older than 18 years who underwent decortication for empyema in STS-GTSD participating institutions from January 1, 2009, to June 30, 2016. The following procedures were included: thoracoscopic partial pulmonary decortication (Current Procedural Terminology [CPT] 32651), thoracoscopic total pulmonary decortication (CPT 32652), total pulmonary decortication (CPT 32220), partial pulmonary decortication (CPT 32225), and decortication and parietal pleurectomy (CPT 32320). Operative approach was defined as thoracoscopic (VATS) if the procedure code used was exclusively thoracoscopic partial pulmonary decortication or thoracoscopic total pulmonary decortication. Patients were excluded from the study if there was missing data in the critical study variables. In addition, several other exclusions based on procedure or diagnosis were made to attempt to isolate patients undergoing decortication for a parapneumonic effusion/acute empyema. For example, we excluded patients with a diagnosis of thoracic malignancy or identical admission and surgery date to eliminate "elective" surgical procedures, which were likely to be related to pleural malignancy or a chronic fibrothorax. Likewise, patients were excluded if they underwent rib resection or open pleural drainage to eliminate patients with chronic empyemas. Patients who have undergone prior cardiothoracic surgery were excluded to eliminate patients undergoing decortication for postsurgical complications. Patients undergoing surgery for a hemothorax were also excluded. Finally, patients with potentially confounding diagnoses such as esophageal perforation, traumatic pneumothorax, emphysema, or pleural thickening were excluded as well (Appendix E1). A consort diagram is shown in Table 1. 
TABLE 1. Consort diagram of exclusion criteria

\begin{tabular}{lcc}
\hline \multicolumn{1}{c}{ Exclusions rules applied } & $\begin{array}{c}\text { Observations } \\
\text { excluded }\end{array}$ & $\begin{array}{c}\text { Remaining } \\
\text { observations }\end{array}$ \\
\hline $\begin{array}{l}\text { Decortications with diagnosis of } \\
\text { empyema without fistula or complex } \\
\text { pleural effusion from 2009 to 2016 }\end{array}$ & 10,404 \\
\hline $\begin{array}{l}\text { 1. Exclude those with prior CT surgery } \\
\text { 2. Exclude those with surgery other } \\
\text { decortication }\end{array}$ & 1525 & 8879 \\
\hline $\begin{array}{l}\text { 3. Exclude those with thoracic } \\
\text { malignancy }\end{array}$ & 139 & 8790 \\
\hline $\begin{array}{l}\text { 4. Exclude those with other } \\
\text { miscellaneous primary or secondary } \\
\text { diagnosis }\end{array}$ & 510 & 8141 \\
\hline $\begin{array}{l}\text { 5. Exclude those with admission date } \\
\text { same as surgery date }\end{array}$ & 790 & 7351 \\
\hline 6. Include the first eligible operation per \\
patient after exclusions 1-6
\end{tabular}

\section{Outcome Measures}

Patients were defined as having a complication if the complication occurred during the hospital admission or the 30 days after a procedure. Complications were categorized according to established definitions, and the severity of each complication was not collected. The definition of major morbidity was based on previous publication and defined as any of the following postoperative events: unexpected return to the operating room, air leak more than 5 days, ventilator support more than 48 hours, tracheostomy, myocardial infarction, deep vein thrombosis or pulmonary embolism, new renal failure (per RIFLE criteria), surgical site infection, or postoperative transfusion. ${ }^{10,11}$ Pneumonia was excluded as a major complication because of possible interrelation with a diagnosis of empyema. Death was defined as in-hospital or 30-day mortality from the procedure. Postoperative length of stay was defined as the number of days from initial operative intervention to discharge. Readmission was defined as readmission to any hospital within 30 days from surgery or discharge (as noted).

\section{Statistical Methods}

Continuous variables are summarized as median and interquartile range. Frequencies and percentages are presented for categoric variables. The differences across groups are assessed using the Kruskal-Wallis test for continuous variables and using chi-square test for categoric variables. Multivariable models used logistic regression for binary outcomes. A subgroup analysis was performed to determine the significance of conversion from a thoracoscopic to open approach. This variable was only available on patients who received their procedure from September 22, 2014, to June 30, 2016, and all analyses related to conversion were only performed on this subgroup.

To assess the impact of patient preoperative risk factors and procedure on each end point, we present risk estimate (ie, odds ratio [OR]) and corresponding confidence interval using the logistic regression with random intercept (participant) to account for statistical dependence between outcomes of patient at the same participant. The covariates, listed in casemix adjustment, were included in the initial model and the final covariates were decided on the basis of backward selection with an alpha for exclusion of 0.05 . All continuous variables were tested for linearity using restricted cubic splines, and nonlinearity relationships were accounted for using linear splines. For each outcome, we assessed the functional form of continuous variables using restricted cubic splines plots with 4 knots after

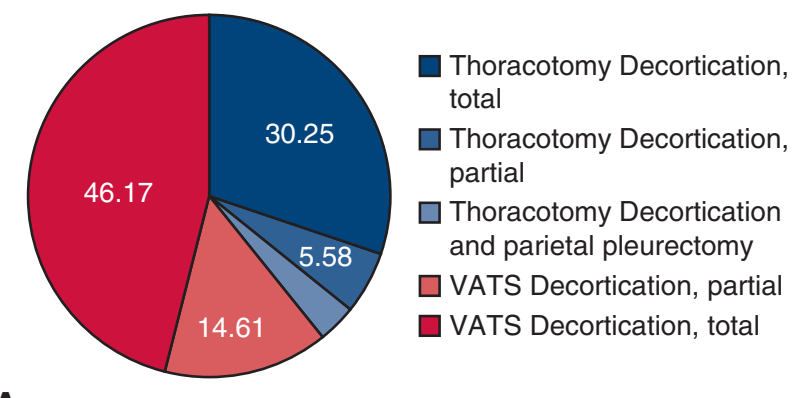

A

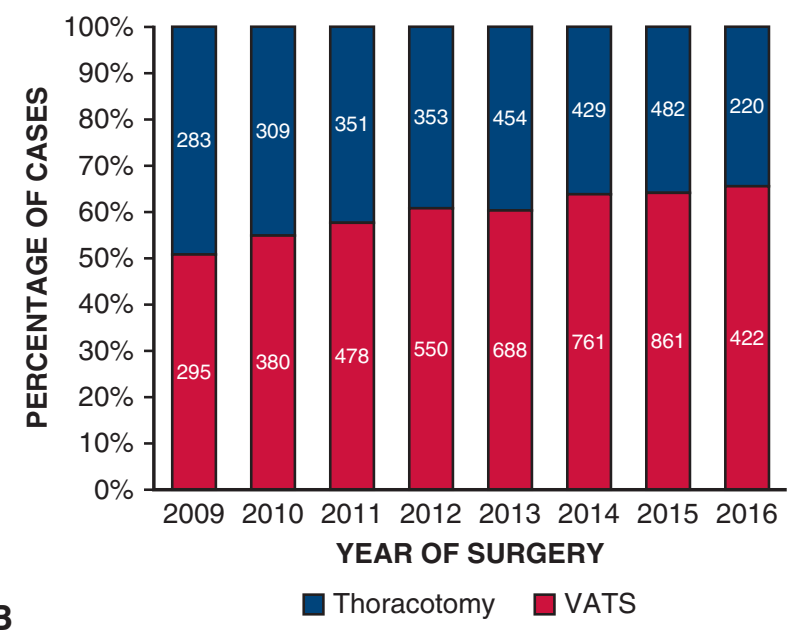

FIGURE 1. Procedures performed during the study period. A, Proportion of each surgical procedure performed. B, Relationship of surgical approach and calendar year of procedure.

full adjustment. Nonlinear relationships were accounted for using linear splines and the appropriate knots. ${ }^{12}$

The missing rates for covariate and outcome data are less than $2 \%$ in most cases and in no case is greater than $6 \%$. All regression models include patients with complete data for covariates and outcomes.

$P$ values of less than .05 were considered to be statistically significant, and there was no adjustment made for multiplicity of comparisons. All statistical calculations were performed using SAS software Version 9.4. (SAS Institute, Inc, Cary, NC).

\section{RESULTS}

During the study period, 7316 procedures were performed at 263 institutions. More than $95 \%$ of patients had a primary diagnosis of empyema without fistula $(n=6961)$, with a minority with diagnoses of "pleural effusion, infected" $(\mathrm{n}=66)$, "pleural effusion, sterile" $(n=62)$, lung abscess $(n=61)$, and others $(n=27)$. A total decortication was performed in $76.4 \%$, a partial decortication was performed in $20.2 \%$, and a pleurectomy was performed in $3.4 \%$ (Figure 1, $A$ ). As shown in Figure 1, $B$, open procedures were performed in 2869 patients $(39.2 \%)$ and thoracoscopic procedures were performed in 4447 patients $(60.8 \%)$. The use of thoracoscopy increased in frequency over time $(P$ value by Cochran-Armitage test $<.001)$ 
with $51 \%$ of procedures performed by VATS in $2010(295 /$ 578 ) compared with $64 \%$ in $2015(861 / 1343)$ and $66 \%$ in the first 6 months of $2016(422 / 642)$.

Table 2 shows the characteristics of patients in this study stratified by operative approach (thoracoscopic or open). The median age of this cohort was 55 years (range, 4465 years). Approximately two-thirds of patients were male $(67 \%)$ and primarily white $(81.8 \%)$. As expected, many patients had significant comorbidities, with most $(87.9 \%)$ classified as ASA Class III or IV. Most patients $(60.9 \%)$ were current or former smokers. Significant medical comorbidities including hypertension $(47.8 \%)$, diabetes $(22.3 \%)$, and COPD $(16.6 \%)$ were common. In comparison with patients who underwent a VATS decortication, patients who received decortication by thoracotomy were more likely to be male $(P=.0023)$, white $(P=.0344)$, current smokers $(P=.0238)$, and on dialysis preoperatively $(P=.0084)$. ASA and Zubrod scores distributions were also significantly different $(P=.0003$ and $P<.0001$, respectively).

Outcomes after decortication are shown in Table 3. Perioperative mortality occurred in 228 patients $(3.1 \%$; $95 \%$ confidence interval, 2.7-3.5). Postoperative complications occurred in 2875 patients $(39.3 \%, 95 \%$ confidence interval, 38.2-40.4), with major morbidity occurring in 2212 (30.2\%, 95\% confidence interval, 29.2-31.3). The most common major complications were the need for transfusion intraoperatively or postoperatively $(26.3 \%, 95 \%$ confidence interval, 25.3-27.4) and the need for initial postoperative ventilator support for more than 48 hours $(6.8 \%, 95 \%$ confidence interval, 6.2-7.4). Median postoperative length of stay was 7 days (IQR, 5-11 days). A total of 707 patients $(9.7 \%)$ had a postoperative LOS more than 19 days, which we defined as prolonged LOS (PLOS) because it corresponded to the 90th percentile of overall LOS for the entire cohort. Transitional care before returning home was required in 1748 patients $(24.2 \%, 95 \% \mathrm{CI}, 23.2-25.2)$. Readmission within 30 days of discharge occurred in 452 patients $(9.2 \%, 95 \% \mathrm{CI}, 8.4-10.1)$.

Patients who received thoracoscopic decortication experienced decreased operative mortality compared with the open group $(2.8 \%$ vs $3.7 \%, P=.0257)$, as well as decreased major morbidity $(13.9 \%$ vs $18.0 \%, P<.0001)$. Both procedure time (median, 85 minutes; range, 60-118 vs 114 minutes; range, $82-158$ minutes, $P<.0001)$ and need for transfusion $(20.6 \%$ vs $30.1 \%, P<.0001)$ were lower in the VATS group. Likewise, patients in the VATS group had shorter LOS (median, 11.5 days [IQR, 8-17] vs 13 days [IQR], 9-20, $P<.0001)$ and less incidence of PLOS $(8.2 \%$ vs $11.9 \%, P<.0001)$ than patients in the open group. Finally, patients were more likely to be discharged to home after a VATS decortication compared with decortication performed through thoracotomy (75.5\% vs $70.9 \%, P=.0002)$. There was no difference in readmission rates between patients undergoing VATS versus open decortication ( $9 \%$ vs $8 \%, P=.2889)$.

To analyze the outcomes of decortications that were started thoracoscopically and converted to an open procedure, we analyzed the subgroup of patients in whom conversion was categorized (September 22, 2014, to June 30, $2016, \mathrm{n}=1985)$. Conversion from VATS to open occurred in 213 of 1496 patients $(14.2 \%)$ whose procedure started thoracoscopically. In this subgroup, patients were similar in regard to preoperative characteristics (Table E2). Outcomes of decortication stratified by conversion are shown in Table 4. There was no difference in mortality between the VATS and conversion groups, although rates of major morbidity were higher in the conversion group than in the VATS group $(20.2 \%$ vs $13.8 \%, P=.0036)$. Relative to VATS, procedures that were converted from VATS to open had longer procedure times (124 minutes; range, 89177.5 vs 82 minutes, range, $58-112$ minutes, $P<.0001)$ and an increased need for transfusion $(37.6 \%$ vs $18.2 \%$, $P<.0001)$. Patients in the VATS group had a shorter LOS (11 days; IQR, 8-16 vs 12 days; IQR, 9-17 days, $P<.0001)$ than the conversion group. There was no difference in discharge to transitional care or readmission rates between the VATS and conversion groups.

To determine which factors were independently associated with adverse outcomes, we performed a multivariable analysis to assess the impact of patient and procedure characteristics on operative mortality, major morbidity, prolonged postoperative length of stay, and discharge to transitional care (Table 5). Older age, poor renal function as evidenced by preoperative eGFR less than 60 , elevated BMI, COPD, and decreased functional status were associated with increased mortality, morbidity, need for discharge to transitional care, and PLOS. The relationship of BMI specifically to these outcomes other than mortality was complex. In the mortality analysis increasing BMI associated with mortality. In the analysis of major morbidity, discharge to transitional care, prolonged length of stay, and increasing or decreasing BMI (from 27) were associated with increased risk of these outcomes. VATS was associated with lower rates of these adverse outcomes compared with thoracotomy. To address potential differences among the cohorts of patients receiving VATS and thoracotomy, we performed separate logistic regression analyses on each group (Table E3, $A$ and $B$ ). These models also demonstrated the relationship of age, renal function, BMI, COPD, and decreased functional status to adverse outcomes.

In this cohort, median time from admission to intervention was 4 days (IQR, 2-7). In the multivariable analysis, each day surgery was delayed from admission until hospital day 5 was associated with a relative increase in mortality by $20 \%$ (95\% CI, 1.07-1.33; $P=.0015)$. When preoperative hospitalization extended beyond 5 days, risk of major morbidity $(P=.0011)$, PLOS $(P<.0001)$, and discharge 
TABLE 2. Description of cohort: Patient characteristics and relationship to procedure performed

\begin{tabular}{|c|c|c|c|c|}
\hline Effects & Overall $N=7316$ & $\begin{array}{c}\text { Thoracotomy } \\
\text { decortication } N=2881\end{array}$ & $\begin{array}{l}\text { VATS decortication } \\
\qquad \mathbf{N}=\mathbf{4 4 3 5}\end{array}$ & $P$ value \\
\hline Age (y) & $55.0(44.0-65.0)$ & $55.0(44.0-64.0)$ & $55.0(44.0-66.0)$ & .1773 \\
\hline \multicolumn{5}{|l|}{ Gender } \\
\hline Male & $4899(67.0 \%)$ & $1989(69.0 \%)$ & $2910(65.6 \%)$ & .0023 \\
\hline \multicolumn{5}{|l|}{ Race } \\
\hline White & $5981(81.8 \%)$ & $2387(82.9 \%)$ & $3594(81.0 \%)$ & .0344 \\
\hline Black & $886(12.1 \%)$ & $345(12.0 \%)$ & $541(12.2 \%)$ & \\
\hline Other & $357(4.9 \%)$ & $118(4.1 \%)$ & $239(5.4 \%)$ & \\
\hline Missing & $92(1.3 \%)$ & $31(1.1 \%)$ & $61(1.4 \%)$ & \\
\hline \multicolumn{5}{|l|}{ BMI $\left(\mathrm{kg} / \mathrm{m}^{2}\right)$} \\
\hline Median (IQR) & $27.1(23.0-32.3)$ & $27.3(23.0-32.8)$ & $27.0(23.0-32.1)$ & .0557 \\
\hline \multicolumn{5}{|l|}{ American Society of Anesthesiologists Risk Class } \\
\hline I & $23(0.3 \%)$ & $13(0.5 \%)$ & $10(0.2 \%)$ & .0003 \\
\hline II & $820(11.2 \%)$ & $284(9.9 \%)$ & $536(12.1 \%)$ & \\
\hline III & $4305(58.8 \%)$ & $1666(57.8 \%)$ & $2639(59.5 \%)$ & \\
\hline IV & $2127(29.1 \%)$ & $895(31.1 \%)$ & $1232(27.8 \%)$ & \\
\hline V/VI & $35(0.5 \%)$ & $19(0.6 \%)$ & $16(0.4 \%)$ & \\
\hline \multicolumn{5}{|l|}{ Zubrod score } \\
\hline Normal activity, no symptoms & $260(3.6 \%)$ & $90(3.1 \%)$ & $170(3.8 \%)$ & $<.0001$ \\
\hline Symptoms but fully ambulatory & $2690(36.8 \%)$ & $1140(39.6 \%)$ & $1550(34.9 \%)$ & \\
\hline Symptoms but in bed $<50 \%$ of the time & $1929(26.4 \%)$ & $727(25.2 \%)$ & $1202(27.1 \%)$ & \\
\hline Symptoms but in bed $>50 \%$ but $<100 \%$ & $1503(20.5 \%)$ & $531(18.4 \%)$ & $972(21.9 \%)$ & \\
\hline Bedridden & $874(11.9 \%)$ & $367(12.7 \%)$ & $507(11.4 \%)$ & \\
\hline Moribund & $56(0.8 \%)$ & $25(0.9 \%)$ & $31(0.7 \%)$ & \\
\hline Coronary artery disease & $669(9.1 \%)$ & $279(9.7 \%)$ & $390(8.8 \%)$ & .1979 \\
\hline Cerebrovascular disease & $426(5.8 \%)$ & $156(5.4 \%)$ & $270(6.1 \%)$ & .2081 \\
\hline Congestive heart failure & $382(5.2 \%)$ & $167(5.8 \%)$ & $215(4.8 \%)$ & .0749 \\
\hline Hypertension & $3497(47.8 \%)$ & $1400(48.6 \%)$ & $2097(47.3 \%)$ & .3044 \\
\hline Diabetes mellitus & $1631(22.3 \%)$ & $670(23.3 \%)$ & $961(21.7 \%)$ & .1157 \\
\hline Steroid & $408(5.6 \%)$ & $158(5.5 \%)$ & $250(5.6 \%)$ & .7760 \\
\hline Chronic obstructive pulmonary disease & $1213(16.6 \%)$ & $502(17.4 \%)$ & $711(16.0 \%)$ & .1185 \\
\hline Peripheral vascular disease & $251(3.4 \%)$ & $105(3.6 \%)$ & $146(3.3 \%)$ & .4200 \\
\hline Preoperative dialysis & $235(3.2 \%)$ & $112(3.9 \%)$ & $123(2.8 \%)$ & .0084 \\
\hline eGFR using Cockcroft-Gault formula & $113.2(77.1-154.3)$ & $113.8(77.7-155.3)$ & $112.9(76.5-153.7)$ & .5052 \\
\hline \multicolumn{5}{|l|}{ Cigarette use } \\
\hline Never smoked & $2829(38.7 \%)$ & $1084(37.6 \%)$ & $1745(39.3 \%)$ & .0238 \\
\hline Past smoker (stopped $\geq 1$ mo before operation) & $2213(30.2 \%)$ & $855(29.7 \%)$ & $1358(30.6 \%)$ & \\
\hline Current smoker & $2244(30.7 \%)$ & $933(32.4 \%)$ & $1311(29.6 \%)$ & \\
\hline
\end{tabular}

to transitional care $(P<.0001)$ also increased with longer delay to surgery. In addition, readmission was also more likely with longer delays from admission to surgery $(P=.0260)$.

\section{DISCUSSION}

Empyema is becoming an increasingly common condition encountered by health care providers in the United States. ${ }^{2,13}$ These data show that patients undergoing decortication for parapneumonic empyema performed by surgeons participating in the Society of Thoracic Surgeons General Thoracic Surgery Database experience low operative mortality $(3.1 \%)$, whereas any and major postoperative complications occur frequently $(39.3 \%$ and $30.2 \%$, respectively). The mortality associated with operative intervention in this cohort is less than a statewide assessment of operative intervention in Washington State, which showed that $5.4 \%$ of patients 
TABLE 3. Outcomes of decortication by operative approach

\begin{tabular}{|c|c|c|c|c|}
\hline Outcome & $\begin{array}{c}\text { Overall } \\
N=7316 \\
\end{array}$ & $\begin{array}{c}\text { Thoracotomy } \\
\text { decortication } N=\mathbf{2 8 8 1}\end{array}$ & $\begin{array}{l}\text { VATS decortication } \\
\qquad N=\mathbf{4 4 3 5} \\
\end{array}$ & $P$ value \\
\hline Duration of procedure (min) & $95.0(68.0-134.0)$ & $114.0(82.0-158.0)$ & $85.0(60.0-118.0)$ & $<.0001$ \\
\hline Length of stay (d) & $12.0(8.0-18.0)$ & $13.0(9.0-20.0)$ & $11.5(8.0-17.0)$ & $<.0001$ \\
\hline Time (d) from admit to surgery & $4.0(2.0-7.0)$ & $4.0(2.0-8.0)$ & $4.0(2.0-7.0)$ & .0001 \\
\hline Postoperative length of stay (d) & $7.0(5.0-11.0)$ & $8.0(6.0-13.0)$ & $7.0(5.0-11.0)$ & $<.0001$ \\
\hline Prolonged postoperative LOS ( $>19$ d) & $707(9.7 \%)$ & $343(11.9 \%)$ & $364(8.2 \%)$ & $<.0001$ \\
\hline Any postoperative event & $2875(39.3 \%)$ & $1306(45.3 \%)$ & $1569(35.4 \%)$ & $<.0001$ \\
\hline Unexpected reoperation & $281(3.8 \%)$ & $129(4.5 \%)$ & $152(3.4 \%)$ & .0224 \\
\hline Air leak $>5 \mathrm{~d}$ duration & $257(3.5 \%)$ & $117(4.1 \%)$ & $140(3.2 \%)$ & .0401 \\
\hline Atelectasis requiring bronchoscopy & $235(3.2 \%)$ & $117(4.1 \%)$ & $118(2.7 \%)$ & .0009 \\
\hline Pulmonary embolus & $26(0.4 \%)$ & $10(0.3 \%)$ & $16(0.4 \%)$ & .9236 \\
\hline Ventilator support $>48 \mathrm{~h}$ & $497(6.8 \%)$ & $242(8.4 \%)$ & $255(5.7 \%)$ & $<.0001$ \\
\hline Reintubation & $198(3.7 \%)$ & $102(4.7 \%)$ & $96(3.0 \%)$ & .0019 \\
\hline Tracheostomy & $199(2.7 \%)$ & $104(3.6 \%)$ & $95(2.1 \%)$ & .0002 \\
\hline Other pulmonary events & $207(2.8 \%)$ & $81(2.8 \%)$ & $126(2.8 \%)$ & .9407 \\
\hline Respiratory failure & $154(4.8 \%)$ & $80(6.5 \%)$ & $74(3.7 \%)$ & .0003 \\
\hline Wound infection & $5(0.2 \%)$ & $4(0.4 \%)$ & $1(0.1 \%)$ & .1152 \\
\hline Unexpected admission to ICU & $260(3.6 \%)$ & $102(3.5 \%)$ & $158(3.6 \%)$ & .9602 \\
\hline New renal failure per RIFLE criteria & $164(3.1 \%)$ & $69(3.6 \%)$ & $95(2.9 \%)$ & .1828 \\
\hline Red cell transfusion (intraoperative, postoperative) & $1926(26.3 \%)$ & $1012(35.1 \%)$ & $914(20.6 \%)$ & $<.0001$ \\
\hline Respiratory failure or ARDS & $314(4.3 \%)$ & $154(5.3 \%)$ & $160(3.6 \%)$ & .0003 \\
\hline \multicolumn{5}{|l|}{ Discharge location } \\
\hline Home & $5394(73.7 \%)$ & $2044(70.9 \%)$ & $3350(75.5 \%)$ & \\
\hline Extended care, TCU, rehabilitation & $1140(15.6 \%)$ & $486(16.9 \%)$ & $654(14.7 \%)$ & \\
\hline Other hospital & $138(1.9 \%)$ & $70(2.4 \%)$ & $68(1.5 \%)$ & \\
\hline Nursing home & $311(4.3 \%)$ & $137(4.8 \%)$ & $174(3.9 \%)$ & \\
\hline Hospice & $54(0.7 \%)$ & $17(0.6 \%)$ & $37(0.8 \%)$ & \\
\hline Other & $77(1.1 \%)$ & $37(1.3 \%)$ & $40(0.9 \%)$ & .0002 \\
\hline $\begin{array}{l}\text { Readmission }-30 \mathrm{~d} \text { of procedure (January } 1,2009 \text {, to } \\
\text { December } 31,2011 \text { ) }\end{array}$ & $144(6.9 \%)$ & $60(6.4 \%)$ & $84(7.3 \%)$ & .4094 \\
\hline $\begin{array}{l}\text { Readmission }-30 \mathrm{~d} \text { of discharge (January } 1,2012 \text {, to } \\
\text { June } 31,2016 \text { ) }\end{array}$ & $452(8.7 \%)$ & $156(8.0 \%)$ & $296(9.0 \%)$ & .2889 \\
\hline Discharged with chest tube & $675(9.2 \%)$ & $288(10.0 \%)$ & $387(8.7 \%)$ & .0664 \\
\hline Operative mortality & $228(3.1 \%)$ & $106(3.7 \%)$ & $122(2.8 \%)$ & .0257 \\
\hline Any major postoperative event & $1138(15.6 \%)$ & $520(18.0 \%)$ & $618(13.9 \%)$ & $<.0001$ \\
\hline Any cardiovascular complications & $494(6.8 \%)$ & $223(7.7 \%)$ & $271(6.1 \%)$ & .0066 \\
\hline Any gastrointestinal complications & $246(3.4 \%)$ & $111(3.9 \%)$ & $135(3.0 \%)$ & .0608 \\
\hline Any urologic complications & $250(3.4 \%)$ & $99(3.4 \%)$ & $151(3.4 \%)$ & .9421 \\
\hline Any neurologic/psychiatric complications & $258(3.5 \%)$ & $100(3.5 \%)$ & $158(3.6 \%)$ & .8357 \\
\hline
\end{tabular}

Primary study end points are boldfaced. Data shown as median (IQR) or N (\%). VATS, Video-assisted thoracoscopic thoracic surgery; LOS, length of stay; ICU, intensive care unit; RIFLE, Risk, Injury, Failure, Loss, End-stage renal disease; $A R D S$, Acute respiratory disease syndrome; TCU, transitional care unit.

died after operative intervention for pleural space infections. ${ }^{13}$ The need for subacute postoperative care is commonly encountered because only $75.8 \%$ of patients are discharged to home. These outcomes are similar to other major thoracic procedures, such as esophagectomy, ${ }^{14}$ and compare favorably to studies that compare operative intervention to nonoperative management. ${ }^{13}$ Understanding these outcomes is critical for surgeons for patient education 
TABLE 4. Outcomes of decortication including analysis of outcomes of conversions from video-assisted thoracoscopic thoracic surgery to open among decortications performed from September 22, 2014, to June 30, 2016

\begin{tabular}{|c|c|c|c|c|}
\hline Outcome & $\begin{array}{l}\text { Open decortication } \\
\qquad \mathbf{N}=\mathbf{4 8 9}\end{array}$ & $\begin{array}{l}\text { VATS decortication } \\
\qquad \mathbf{N}=\mathbf{1 2 8 3}\end{array}$ & $\begin{array}{c}\text { VATS converted to } \\
\text { thoracotomy } N=213\end{array}$ & $P$ value \\
\hline Duration of procedure (min) & $112.0(80.0-150.0)$ & $82.0(58.0-112.0)$ & $124.0(89.0-177.5)$ & $<.0001$ \\
\hline Length of stay (d) & $12.0(9.0-21.0)$ & $11.0(8.0-16.0)$ & $12.0(9.0-17.0)$ & $<.0001$ \\
\hline Time (d) from admit to surgery & $4.0(2.0-7.0)$ & $4.0(2.0-7.0)$ & $3.5(2.0-7.0)$ & .7278 \\
\hline Postoperative length of stay (d) & $8.0(6.0-13.0)$ & $6.0(4.0-10.0)$ & $7.0(5.0-11.0)$ & $<.0001$ \\
\hline Prolonged postoperative LOS $(>19 \mathrm{~d})$ & $69(14.1 \%)$ & $110(8.6 \%)$ & $19(8.9 \%)$ & .0021 \\
\hline Any postoperative event & $226(46.2 \%)$ & $468(36.5 \%)$ & $102(47.9 \%)$ & $<.0001$ \\
\hline Unexpected reoperation & $25(5.1 \%)$ & $48(3.7 \%)$ & $10(4.7 \%)$ & .4030 \\
\hline Air leak $>5 \mathrm{~d}$ duration & $29(5.9 \%)$ & $41(3.2 \%)$ & $8(3.8 \%)$ & .0297 \\
\hline Atelectasis requiring bronchoscopy & $15(3.1 \%)$ & $33(2.6 \%)$ & $5(2.3 \%)$ & .8067 \\
\hline Pulmonary embolus & $5(1.0 \%)$ & $4(0.3 \%)$ & $1(0.5 \%)$ & .1676 \\
\hline Ventilator support $>48 \mathrm{~h}$ & $40(8.2 \%)$ & $56(4.4 \%)$ & $15(7.0 \%)$ & .0047 \\
\hline Tracheostomy & $18(3.7 \%)$ & $28(2.2 \%)$ & $8(3.8 \%)$ & .1374 \\
\hline Other pulmonary events & $17(3.5 \%)$ & $36(2.8 \%)$ & $6(2.8 \%)$ & .7514 \\
\hline Unexpected admission to ICU & $17(3.5 \%)$ & $40(3.1 \%)$ & $8(3.8 \%)$ & .8529 \\
\hline New renal failure per RIFLE criteria & $13(2.7 \%)$ & $39(3.0 \%)$ & $11(5.2 \%)$ & .1977 \\
\hline Red cell (intraoperative, postoperative) & $158(32.3 \%)$ & $234(18.2 \%)$ & $80(37.6 \%)$ & $<.0001$ \\
\hline Respiratory failure or ARDS & $41(8.4 \%)$ & $67(5.2 \%)$ & $19(8.9 \%)$ & .0147 \\
\hline \multicolumn{5}{|l|}{ Discharge location } \\
\hline Home & $342(69.9 \%)$ & $962(75.0 \%)$ & $149(70.0 \%)$ & \multirow{6}{*}{.7644} \\
\hline Extended care, TCU, rehabilitation & $92(18.8 \%)$ & $215(16.8 \%)$ & $42(19.7 \%)$ & \\
\hline Other hospital & $9(1.8 \%)$ & $23(1.8 \%)$ & $4(1.9 \%)$ & \\
\hline Nursing home & $20(4.1 \%)$ & $38(3.0 \%)$ & $9(4.2 \%)$ & \\
\hline Hospice & $3(0.6 \%)$ & $7(0.5 \%)$ & $1(0.5 \%)$ & \\
\hline Other & $6(1.2 \%)$ & $8(0.6 \%)$ & $2(0.9 \%)$ & \\
\hline Readmission within $30 \mathrm{~d}$ of discharge & $43(8.8 \%)$ & $125(9.7 \%)$ & $17(8.0 \%)$ & .6816 \\
\hline Discharged with chest tube & $32(6.5 \%)$ & $96(7.5 \%)$ & $27(12.7 \%)$ & .0177 \\
\hline Operative mortality & $22(4.5 \%)$ & $39(3.0 \%)$ & $6(2.8 \%)$ & .2810 \\
\hline Any major postoperative event & $94(19.2 \%)$ & $177(13.8 \%)$ & $43(20.2 \%)$ & .0036 \\
\hline
\end{tabular}

Data shown as median (IQR) or N (\%). VATS, Video-assisted thoracoscopic thoracic surgery; LOS, length of stay; ICU, intensive care unit; RIFLE, Risk, Injury, Failure, Loss, End-stage renal disease; $A R D S$, Acute respiratory disease syndrome; $T C U$, transitional care unit.

and consent, and highlights the need for ongoing quality improvement in this area.

Several factors were associated with poor outcome after decortication. In multivariable analysis, age, comorbidities (especially poor renal function or preoperative dialysis) and poor functional status were associated with prolonged length of stay, discharge to a location other than home, major morbidity, and mortality. We also demonstrate that delays in operative intervention were associated with poor outcomes, including significant increases in operative mortality in the first 5 days for each day delayed. Two retrospective studies ${ }^{15,16}$ demonstrated that operative delays increase the rate of conversion from VATS to open. However, the independent association with surgical delay and mortality is a novel finding of the current study. This suggests that earlier intervention appears to significantly affect outcomes. Guidelines have not addressed the timing of surgical intervention in empyema, ${ }^{17,18}$ and some early reports of outcomes after decortication recommended delaying definitive decortication 3 days to determine if antibiotics and chest tube drainage "will be effective." 19 This study corroborates recommendations from a Washington State community-based assessments of pleural infections, which highlighted the importance of "early referral for thoracic surgical consultation." 13 Although this retrospective review cannot identify clinical factors that suggest the need for surgical intervention, we believe that the association of delay and poor outcomes suggests that surgeons 
TABLE 5. Multivariable logistic regression of factors associated with postoperative events

\begin{tabular}{|c|c|c|c|c|c|c|c|c|}
\hline \multirow[b]{2}{*}{ Risk factor } & \multicolumn{2}{|c|}{ Major morbidity } & \multicolumn{2}{|c|}{$\begin{array}{l}\text { Discharge location } \\
\text { other than home }\end{array}$} & \multicolumn{2}{|c|}{ Postoperative LOS $>19$ d } & \multicolumn{2}{|c|}{ Mortality } \\
\hline & $\begin{array}{c}\text { Adjusted } \\
\text { OR }(95 \% \mathrm{CI})\end{array}$ & $P$ value & $\begin{array}{c}\text { Adjusted } \\
\text { OR }(95 \% \text { CI })\end{array}$ & $P$ value & $\begin{array}{c}\text { Adjusted } \\
\text { OR }(95 \% \mathrm{CI})\end{array}$ & $P$ value & $\begin{array}{c}\text { Adjusted } \\
\text { OR }(95 \% \text { CI })\end{array}$ & $P$ value \\
\hline Age per 1-y increase & & & & & $0.99(0.98-1.00)$ & .0007 & $1.05(1.03-1.06)$ & $<.0001$ \\
\hline $\begin{array}{c}\text { Age per } 1 \text {-y increase } \\
\text { when age } \leq 40\end{array}$ & $0.98(0.96-1.00)$ & .0095 & $0.98(0.96-0.99)$ & .0114 & & & & \\
\hline $\begin{array}{l}\text { Age per } 1 \text {-y increase } \\
\text { when }<40 \text { y age } \leq 67\end{array}$ & $1.02(1.01-1.03)$ & $<.0001$ & $1.04(1.03-1.05)$ & $<.0001$ & & & & \\
\hline $\begin{array}{l}\text { Age per } 1-y \text { increase } \\
\text { when }>67 y\end{array}$ & $0.98(0.97-1.00)$ & .0247 & $1.08(1.06-1.10)$ & $<.0001$ & & & & \\
\hline Female & $1.19(1.06-1.34)$ & .0039 & $1.26(1.10-1.45)$ & .0008 & & & & \\
\hline BMI per $1 \mathrm{~kg} / \mathrm{m}^{2}$ increase & & & & & & & $0.97(0.95-0.99)$ & .0071 \\
\hline $\begin{array}{l}\text { BMI per } 1 \mathrm{~kg} / \mathrm{m}^{2} \\
\text { increase when BMI } \\
\leq 27\end{array}$ & $0.95(0.93-0.97)$ & $<.0001$ & $0.95(0.92-0.97)$ & $<.0001$ & $0.95(0.92-0.98)$ & .0010 & & \\
\hline $\begin{array}{l}\text { BMI per } 1 \mathrm{~kg} / \mathrm{m}^{2} \\
\text { increase when BMI } \\
\geq 27\end{array}$ & $1.02(1.00-1.03)$ & .0047 & $1.03(1.01-1.04)$ & $<.0001$ & $1.01(1.00-1.03)$ & .0576 & & \\
\hline Steroid & & & & & & & $1.74(1.10-2.74)$ & .0172 \\
\hline Congestive heart failure & $1.36(1.07-1.73)$ & .0126 & $1.70(1.30-2.22)$ & .0001 & & & $1.72(1.15-2.58)$ & .0081 \\
\hline $\begin{array}{l}\text { Cerebrovascular } \\
\text { disease }\end{array}$ & $1.36(1.09-1.71)$ & .0067 & $2.67(2.10-3.39)$ & $<.0001$ & & & & \\
\hline Diabetes & $1.22(1.07-1.40)$ & .0039 & $1.18(1.01-1.38)$ & .0363 & $1.36(1.12-1.66)$ & .0021 & & \\
\hline Dialysis & & & $1.60(1.11-2.29)$ & .0113 & & & $2.23(1.33-3.77)$ & .0026 \\
\hline eGFR $<60$ & $1.81(1.54-2.12)$ & $<.0001$ & $1.48(1.23-1.79)$ & $<.0001$ & $2.25(1.82-2.77)$ & $<.0001$ & $1.94(1.38-2.74)$ & .0002 \\
\hline COPD & $1.26(1.09-1.46)$ & .0019 & $1.30(1.10-1.53)$ & .0018 & $1.42(1.15-1.76)$ & .0013 & $1.49(1.08-2.04)$ & .0139 \\
\hline $\begin{array}{l}\text { ASA risk class: III/IV/ } \\
\text { V/VI vs I/II }\end{array}$ & $2.07(1.66-2.60)$ & $<.0001$ & $2.28(1.70-3.07)$ & $<.0001$ & $4.51(2.60-7.82)$ & $<.0001$ & $10.15(1.41-73.12)$ & .0215 \\
\hline $\begin{array}{l}\text { Zubrod: in bed/bedridden/ } \\
\text { moribund vs normal } \\
\text { activity/fully } \\
\text { ambulatory }\end{array}$ & $1.84(1.62-2.09)$ & $<.0001$ & $2.34(2.01-2.73)$ & $<.0001$ & $2.33(1.88-2.88)$ & $<.0001$ & $2.46(1.69-3.57)$ & $<.0001$ \\
\hline VATS & $0.69(0.60-0.78)$ & $<.0001$ & $0.74(0.64-0.85)$ & $<.0001$ & $0.79(0.65-0.96)$ & .0162 & $0.74(0.56-0.99)$ & .0444 \\
\hline $\begin{array}{l}\text { Days from admission to } \\
\text { surgery per 1-d increase } \\
\text { when } \leq 5 \mathrm{~d}\end{array}$ & $1.02(0.98-1.06)$ & .4244 & $1.01(0.96-1.06)$ & .7732 & $1.09(1.02-1.16)$ & .0127 & $1.20(1.07-1.33)$ & .0015 \\
\hline $\begin{array}{l}\text { Days from admission to } \\
\text { surgery per 1-d increase } \\
\text { when }>5 \mathrm{~d}\end{array}$ & $1.02(1.01-1.04)$ & .0011 & 1.07 (1.06-1.09) & $<.0001$ & $1.07(1.05-1.09)$ & $<.0001$ & $1.02(1.00-1.05)$ & .0782 \\
\hline $\begin{array}{l}\text { Procedure time per } \\
10 \text {-min increase }\end{array}$ & $1.05(1.04-1.06)$ & $<.0001$ & & & $1.03(1.02-1.05)$ & $<.0001$ & & \\
\hline
\end{tabular}

Covariates selected by reverse selection from univariate model. Data presented as odds ratio and $95 \%$ CI. Note: Patients with missing covariates ( $\mathrm{n}=445,6 \%$ ) were excluded in this analysis. Depending on the missingness of each variable included in each end point, the final cohort varied. LOS, Length of stay; $O R$, odds ratio; $C I$, confidence interval; $B M I$, body mass index; $e G F R$, estimated glomerular filtration rate; COPD, chronic obstructive pulmonary disease; ASA, American Society of Anesthesiologists; VATS, video-assisted thoracoscopic surgery.

should consider more urgent intervention in patients in whom surgery is likely "inevitable." Furthermore, unlike medical comorbidities, the timing of a procedure may be one of the few variables that can be controlled.

This study also evaluated the relationship of thoracoscopic procedures to outcome. VATS was increasingly common during the study period. In subgroup analysis, the conversion rate from VATS to thoracotomy was $14 \%$, which is lower than many contemporary series. ${ }^{7,15} \mathrm{We}$ hypothesize that this may be due to increased expertise in minimally invasive techniques among institutions participating in the STS database. Conversion from VATS 


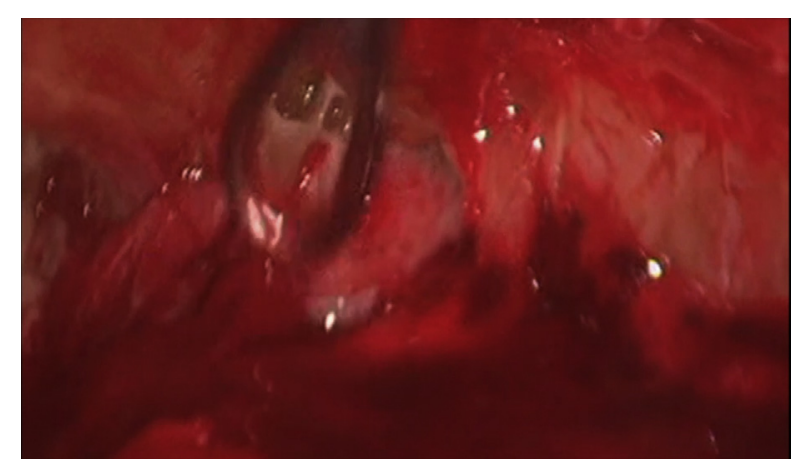

VIDEO 1. Demonstration of a VATS decortication. Video available at: https://www.jtcvs.org/article/S0022-5223(18)33151-9/fulltext.

to open thoracotomy did not appreciably change the outcomes of patients compared with those who underwent thoracotomy as the initial approach. One exception to this was "discharge with a chest tube," which was elevated among conversion patients. We hypothesize that the increased rate of discharge with a chest tube in this group is due to incomplete lung expansion/persistent space possibly due to advanced disease among these patients. The use of a chest tube is not likely to be secondary to iatrogenic lung injury because prolonged air leak was not higher in the conversion group. Although VATS was associated with improved mortality, complication rates, and length of stay, we caution against the conclusion that VATS is a "better" approach. Neither this current study nor the STS-GTSD is able to match patient cohorts to make a meaningful comparison because there are unmeasured variables, such as disease severity, which can have substantial confounding on the relationship of thoracotomy to other outcomes. Nonetheless, our findings corroborate guidelines, which suggest that VATS "should be the firstline approach in all patients with stage II acute empyema" and there is "little potential harm of VATS as an initial intervention." 17,18 The ability to successfully perform thoracoscopic decortication is governed by many variables that include: patient pathophysiology, severity of intrathoracic inflammation, and surgeon preference and technical skills (Video 1).

\section{Study Limitations}

The retrospective study has several weaknesses. Because of the retrospective nature of the study, comparisons between the groups are observational in nature, and these data should not be used to conclude superiority of a given approach or operative technique. The microbiology and severity/stage of empyema is not accurately captured in this database, and may be a significant confounder in outcome. Furthermore, preoperative management might have altered treatment outcomes, either through antibiotic treatment or pleural drainage, and is also not captured in the database and therefore not considered in this analysis. Another limitation in this study is that we have excluded certain patients for the purposes of creating a homogeneous population for analysis. Excluding patients with a concurrent diagnosis of cancer or previous cardiothoracic surgery, for example, may have significantly altered our findings. We believe that this analysis is nonetheless meaningful to describe the contemporary outcomes of decortication of parapneumonic empyema and can act as the foundation for possible future studies.

\section{CONCLUSIONS}

This is the largest analysis of outcomes after decortication for empyema and complex pleural effusion. We believe that this study defines the status of decortication among institutions participating in the STS-GTSD. These outcomes measures reflect a large cohort and the pooled experience of hundreds of surgeons and institutions. These data provide valuable information, which may be used for patient and family counseling regarding postoperative expectations, especially given the high rates of complications and discharge to locations other than home. Ideally, these data also can be used for quality improvement initiatives, which are currently lacking in treatment of empyema. Although these data cannot be used to determine the ideal operative approach or the ideal time to perform decortication, we believe that the association of operative delay and poor outcome is troubling and that further research in this area is appropriate.

\section{Conflict of Interest Statement}

C.W.T. discloses that he is a consultant to Medtronic and AtriCure, but this relationship has not influenced the work or its conclusions. All other authors have nothing to disclose with regard to commercial support.

\section{References}

1. Grijalva CG, Zhu Y, Nuorti JP, Griffin MR. Emergence of parapneumonic empyema in the USA. Thorax. 2011;66:663-8.

2. HCUP Clinical Classifications Software for Services and Procedures. Rockville, MD: Agency for Healthcare Research and Quality; 2008. Available at: https:// hcupnet.ahrq.gov/. Accessed April 20, 2017.

3. Mikkola R, Kelahaara J, Heikkinen J, Lahtinen J, Biancari F. Poor late survival after surgical treatment of pleural empyema. World J Surg. 2010;34: 266-71.

4. Schweigert M, Solymosi N, Dubecz C, Fernández MJ, Stadlhuber RJ, Ofner D, et al. Surgery for parapneumonic pleural empyema-what influence does the rising prevalence of multimorbidity and advanced age has on the current outcome? Surgeon. 2016;14:69-75

5. Tong BC, Hanna J, Toloza EM, Onaitis MW, D’Amico TA, Harpole DH, et al. Outcomes of video-assisted thoracoscopic decortication. Ann Thorac Surg. 2010;89:220-5.

6. Schweigert M, Solymosi N, Dubecz A, Beron M, Thumfart L, Oefner-Velano D, et al. Surgical management of pleural empyema in the very elderly. Ann R Coll Surg Engl. 2012;94:331-5.

7. Stefani A, Aramini B, della Casa G, Ligabue G, Kaleci S, Casali C, et al. Preoperative predictors of successful surgical treatment in the management of parapneumonic empyema. Ann Thorac Surg. 2013;96:1812-9. 
8. Shahin Y, Duffy J, Beggs D, Black E, Majewski A. Surgical management of primary empyema of the pleural cavity: outcome of 81 patients. Interact Cardiovasc Thorac Surg. 2010;10:565-7.

9. Society of Thoracic Surgeons. Available at: www.sts.org. Accessed September 5, 2017.

10. Fernandez FG, Kosinski AS, Burfeind W, et al. The Society of Thoracic Surgeons lung cancer resection risk model: higher quality data and superior outcomes. Ann Thorac Surg. 2016;102:370-7.

11. Kozower BD, O'Brien SM, Kosinski AS, Magee MJ, Dokholyan R, Jacobs JP, et al. The Society of Thoracic Surgeons composite score for rating program performance for lobectomy for lung cancer. Ann Thorac Surg. 2016;101:1379-87.

12. Desquilbet L, Mariotti F. Dose-response analyses using restricted cubic spline functions in public health research. Stat Med. 2010;29:1037-57.

13. Farjah F, Symons RG, Krishnadasan B, Wood DE, Flum DR. Management of pleural space infections: a population-based analysis. J Thorac Cardiovasc Surg. 2007; 133:346-51.

14. Wright CD, Kucharczuk JC, O'Brien SM, Grab JD, Allen MS, Society of Thoracic Surgeons General Thoracic Surgery Database. Predictors of major morbidity and mortality after esophagectomy for esophageal cancer: a Society of Thoracic Surgeons general thoracic surgery database risk adjustment model. J Thorac Cardiovasc Surg. 2009;137:587-96.
15. Lardinois D, Gock M, Pezzetta E, Buchli C, Rousson V, Furrer M, et al. Delayed referral and gram-negative organisms increase the conversion thoracotomy rate in patients undergoing video-assisted thoracoscopic surgery for empyema. Ann Thorac Surg. 2005;79:1851-6.

16. Waller DA, Rengarajan A, Nicholson FH, Rajesh PB. Delayed referral reduces the success of video-assisted thoracoscopic debridement for post-pneumonic empyema. Respir Med. 2001;95:836-40.

17. Scarci M, Abah U, Solli P, Page A, Waller D, van Schil P, et al. EACTS expert consensus statement for surgical management of pleural empyema. Eur J Cardiothorac Surg. 2015;48:642-53.

18. Shen KR, Bribriesco A, Crabtree T, Denlinger C, Eby J, Eiken P, et al The American Association for Thoracic Surgery consensus guidelines for the management of empyema. J Thorac Cardiovasc Surg. 2017;153: e129-46.

19. Ashbaugh DG. Empyema thoracis. Factors influencing morbidity and mortality Chest. 1991;99:1162-5.

Key Words: empyema, decortication, parapneumonic effusion, surgery 
TABLE E1. Diagnoses that were exclusion criteria

- Tracheal tumor, malignant

- Tracheal tumor, metastatic

- Anterior mediastinal tumor primary (germ cell cancer, seminoma)

- Anterior mediastinal tumor-metastatic

- Anterior mediastinal tumor-thymus tumor (thymoma, thymic carcinoma)

- Lymphoma, intrathoracic

- Mediastinal nodes, metastatic

- Posterior mediastinal malignant tumor, primary

- Posterior mediastinal tumor, metastatic

- Thyroid neoplasm, malignant

- Pleural effusion, malignant

- Pleural tumor, metastatic

- Pleural tumor, malignant (eg, mesothelioma)

- Malignant neoplasm other specified sites of pleura

- Malignant tumor of pleura, unspecified

- Rib tumor, malignant

- Rib tumor, metastatic

- Sternal tumor, malignant

- Sternal tumor, metastatic

- Diaphragm tumor, malignant

- Diaphragm tumor, metastatic

- Pericardial effusion, malignant

- Malignant neoplasm, connective tissue and other soft tissue of the thorax

- Malignant poorly differentiated neuroendocrine carcinoma, any site

- Secondary malignant neoplasm of other specified sites

- Carcinoid tumor of the bronchus and lung; malignant, atypical

- Lung cancer, not specified

- Lung cancer, main bronchus, carina

- Lung cancer, upper lobe

- Lung cancer, middle lobe

- Lung cancer, lower lobe

- Lung cancer, location unspecified

- Lung tumor, metastatic

- Malignant neoplasm other parts of bronchus or lung

- Personal history of malignant neoplasm of bronchus and lung

- Esophageal cancer, not specified

- Esophageal cancer, esophagogastric junction (cardia)

- Esophageal cancer, middle third

- Esophageal cancer, upper third

- Esophageal cancer, lower third

- Malignant neo stomach unspecified

- Malignant other part esophagus, specified

- Lung tumor, metastatic

- Hemothorax

- Esophageal perforation

- Epiphrenic diverticulum

- Traumatic pneumothorax

- Traumatic hemothorax

- Esophageal injury

- Diaphragmatic hernia without obstruction or gangrene

- Rib fractures, multiple

- Transplanted lung complication(s)

- Pneumothorax

- Emphysema
TABLE E1. Continued

- Interstitial lung disease/fibrosis

- Solitary pulmonary nodule (not a tumor, eg, granuloma, subpleural lymph node, pulmonary infarct)

- Mediastinitis

- Pleural thickening

- Esophageal stricture

- Traumatic pneumothorax

- Pericarditis with effusion

- Mediastinal abscess

- Chylothorax 
TABLE E2. Preoperative characteristics of a subset of patients undergoing decortication categorized by operative approach, including conversion from VATS to thoracotomy

\begin{tabular}{|c|c|c|c|c|}
\hline Effects & $\begin{array}{c}\text { Thoracotomy } \\
\text { decortication } N=489\end{array}$ & $\begin{array}{l}\text { VATS decortication } \\
\qquad \mathbf{N}=\mathbf{1 2 8 3}\end{array}$ & $\begin{array}{l}\text { VATS converted } \\
\text { to thoracotomy } N=213\end{array}$ & $P$ value \\
\hline Age (y) & $55.0(45.0-64.0)$ & $56.0(44.0-66.0)$ & $55.0(44.0-65.0)$ & .2951 \\
\hline \multicolumn{5}{|l|}{ Gender } \\
\hline Male & $343(70.1 \%)$ & $837(65.2 \%)$ & $142(66.7 \%)$ & .1319 \\
\hline \multicolumn{5}{|l|}{ Race } \\
\hline White & $406(83.0 \%)$ & $1005(78.3 \%)$ & $164(77.0 \%)$ & .2403 \\
\hline Black & $48(9.8 \%)$ & $163(12.7 \%)$ & $26(12.2 \%)$ & \\
\hline Other & $25(5.1 \%)$ & $89(6.9 \%)$ & $15(7.0 \%)$ & \\
\hline BMI $\left(\mathrm{kg} / \mathrm{m}^{2}\right)$ & $27.2(23.2-32.7)$ & $26.9(22.8-32.4)$ & $27.7(22.5-33.8)$ & .4898 \\
\hline American Society of Anesthesiologists Risk Class & & & & .5831 \\
\hline I & $2(0.4 \%)$ & $2(0.2 \%)$ & $0(0.0 \%)$ & \\
\hline II & $51(10.4 \%)$ & $134(10.4 \%)$ & $17(8.0 \%)$ & \\
\hline III & $287(58.7 \%)$ & $773(60.2 \%)$ & $130(61.0 \%)$ & \\
\hline IV & $142(29.0 \%)$ & $370(28.8 \%)$ & $64(30.0 \%)$ & \\
\hline $\mathrm{V}$ & $5(1.0 \%)$ & $4(0.3 \%)$ & $1(0.5 \%)$ & \\
\hline Missing & $2(0.4 \%)$ & $0(0.0 \%)$ & $1(0.5 \%)$ & \\
\hline \multicolumn{5}{|l|}{ Zubrod Score } \\
\hline Normal activity, no symptoms & $10(2.0 \%)$ & $33(2.6 \%)$ & $6(2.8 \%)$ & .2558 \\
\hline Symptoms but fully ambulatory & $171(35.0 \%)$ & $408(31.8 \%)$ & $68(31.9 \%)$ & \\
\hline Symptoms but in bed less than $50 \%$ of the time & $118(24.1 \%)$ & $365(28.4 \%)$ & $65(30.5 \%)$ & \\
\hline Symptoms but in bed $>50 \%$ but less than $100 \%$ & $116(23.7 \%)$ & $328(25.6 \%)$ & $47(22.1 \%)$ & \\
\hline Bedridden & $69(14.1 \%)$ & $144(11.2 \%)$ & $27(12.7 \%)$ & \\
\hline Moribund & $5(1.0 \%)$ & $5(0.4 \%)$ & $0(0.0 \%)$ & \\
\hline Coronary artery disease & $54(11.0 \%)$ & $114(8.9 \%)$ & $19(8.9 \%)$ & .3693 \\
\hline Cerebrovascular disease & $30(6.1 \%)$ & $84(6.5 \%)$ & $18(8.5 \%)$ & .4985 \\
\hline Congestive heart failure & $34(7.0 \%)$ & $69(5.4 \%)$ & $6(2.8 \%)$ & .0829 \\
\hline Hypertension & $232(47.4 \%)$ & $643(50.1 \%)$ & $112(52.6 \%)$ & .4248 \\
\hline Diabetes mellitus & $120(24.5 \%)$ & $323(25.2 \%)$ & $61(28.6 \%)$ & .5062 \\
\hline Steroid & $24(4.9 \%)$ & $76(5.9 \%)$ & $13(6.1 \%)$ & .6855 \\
\hline Chronic obstructive pulmonary disease & $97(19.8 \%)$ & $204(15.9 \%)$ & $41(19.2 \%)$ & .0939 \\
\hline Peripheral vascular disease & $17(3.5 \%)$ & $44(3.4 \%)$ & $12(5.6 \%)$ & .2723 \\
\hline Preoperative dialysis & $17(3.5 \%)$ & $42(3.3 \%)$ & $10(4.7 \%)$ & .5757 \\
\hline eGFR using Cockcroft-Gault formula & $118.3(82.2-161.6)$ & $114.0(78.3-155.7)$ & $123.4(86.7-167.5)$ & .1024 \\
\hline \multicolumn{5}{|l|}{ Cigarette use } \\
\hline Never smoked & $175(35.8 \%)$ & $495(38.6 \%)$ & $69(32.4 \%)$ & .0648 \\
\hline Past smoker (stopped $\geq 1$ mo before operation) & $144(29.4 \%)$ & $400(31.2 \%)$ & $71(33.3 \%)$ & \\
\hline Current smoker & $165(33.7 \%)$ & $367(28.6 \%)$ & $71(33.3 \%)$ & \\
\hline Missing & $5(1.0 \%)$ & $21(1.6 \%)$ & $2(0.9 \%)$ & \\
\hline
\end{tabular}

Data shown as median (IQR) or N (\%). VATS, Video-assisted thoracoscopic surgery; BMI, body mass index; $e G F R$, estimated glomerular filtration rate. 
TABLE E3. Multivariable logistic regression of factors associated with postoperative events among patients receiving thoracotomy

\begin{tabular}{|c|c|c|c|c|c|c|c|c|}
\hline \multirow[b]{2}{*}{ Risk factor } & \multicolumn{2}{|c|}{$\begin{array}{l}\text { Major morbidity } \\
\quad(\mathbf{n}=\mathbf{2 7 2 2})\end{array}$} & \multicolumn{2}{|c|}{$\begin{array}{c}\text { Discharge location } \\
\text { other than home }(n=2646)\end{array}$} & \multicolumn{2}{|c|}{$\begin{array}{c}\text { Postoperative } \\
\text { LOS }>19 d(n=2718) \\
\end{array}$} & \multicolumn{2}{|c|}{$\begin{array}{l}\text { Mortality } \\
(\mathrm{n}=\mathbf{2 7 2 2})\end{array}$} \\
\hline & $\begin{array}{c}\text { Adjusted } \\
\text { OR }(95 \% \text { CI })\end{array}$ & $P$ value & $\begin{array}{c}\text { Adjusted } \\
\text { OR }(\mathbf{9 5} \% \mathrm{CI})\end{array}$ & $P$ value & $\begin{array}{c}\text { Adjusted } \\
\text { OR }(95 \% \text { CI })\end{array}$ & $P$ value & $\begin{array}{c}\text { Adjusted } \\
\text { OR }(95 \% \text { CI })\end{array}$ & $P$ value \\
\hline Age per 1-y increase & & & & & $0.99(0.98-1.00)$ & 0523 & $1.05(1.04-1.07)$ & $<.0001$ \\
\hline $\begin{array}{l}\text { Age per } 1 \text {-y increase } \\
\text { when age } \leq 40 \mathrm{y}\end{array}$ & $0.99(0.97-1.01)$ & .3882 & $0.98(0.95-1.01)$ & .1783 & & & & \\
\hline $\begin{array}{l}\text { Age per 1-y increase } \\
\text { when age }<40 \text { or } \leq 67\end{array}$ & $1.02(1.00-1.03)$ & .0150 & $1.05(1.03-1.06)$ & $<.0001$ & & & & \\
\hline $\begin{array}{l}\text { Age per 1-y increase } \\
\text { when age }>67 y\end{array}$ & $0.99(0.96-1.01)$ & .2457 & $1.09(1.06-1.12)$ & $<.0001$ & & & & \\
\hline Female & $1.16(0.96-1.40)$ & .1370 & $1.36(1.09-1.69)$ & .0056 & & & & \\
\hline BMI per $1 \mathrm{~kg} / \mathrm{m}^{2}$ increase & & & & & & & $0.97(0.94-1.00)$ & .0638 \\
\hline $\begin{array}{l}\text { BMI per } 1 \mathrm{~kg} / \mathrm{m}^{2} \text { increase } \\
\text { when } \mathrm{BMI} \leq 27\end{array}$ & $0.92(0.89-0.95)$ & $<.0001$ & $0.94(0.91-0.98)$ & .0013 & $0.95(0.91-0.99)$ & .0185 & & \\
\hline $\begin{array}{l}\text { BMI per } 1 \mathrm{~kg} / \mathrm{m}^{2} \text { increase } \\
\quad \text { when } \mathrm{BMI} \geq 27\end{array}$ & $1.03(1.02-1.05)$ & $<.0001$ & $1.03(1.01-1.05)$ & .0011 & $1.02(1.00-1.04)$ & .0301 & & \\
\hline Steroid & & & & & & & $1.61(0.76-3.42)$ & .2103 \\
\hline Congestive heart failure & $1.31(0.91-1.90)$ & .1470 & $1.45(0.96-2.20)$ & .0760 & & & $1.87(1.05-3.34)$ & .0349 \\
\hline Cerebrovascular disease & $1.45(1.00-2.09)$ & .0495 & $2.62(1.76-3.92)$ & $<.0001$ & & & & \\
\hline Diabetes & $1.10(0.89-1.36)$ & .3737 & $1.18(0.93-1.50)$ & .1808 & $1.14(0.85-1.54)$ & .3817 & & \\
\hline Dialysis & & & $1.37(0.80-2.34)$ & .2576 & & & $2.13(1.00-4.56)$ & .0511 \\
\hline eGFR $<60$ & $1.83(1.43-2.34)$ & $<.0001$ & $1.76(1.31-2.37)$ & 0.00 .02 & $2.31(1.70-3.15)$ & $<.0001$ & $2.02(1.21-3.37)$ & .0073 \\
\hline COPD & $1.30(1.04-1.63)$ & .0228 & $1.19(0.92-1.53)$ & .1877 & $1.29(0.94-1.77)$ & .1171 & $1.33(0.82-2.16)$ & .2465 \\
\hline $\begin{array}{l}\text { ASA risk class: } \\
\text { III/IV/V/VI vs I/II }\end{array}$ & $1.88(1.32-2.67)$ & .0004 & $1.93(1.21-3.08)$ & .0062 & $3.89(1.77-8.56)$ & .0007 & $4.09(0.55-30.54)$ & .1702 \\
\hline $\begin{array}{l}\text { Zubrod: in bed/bedridden/ } \\
\text { moribund vs normal } \\
\text { activity/fully ambulatory }\end{array}$ & $2.04(1.68-2.47)$ & $<.0001$ & $2.23(1.78-2.80)$ & $<.0001$ & $2.72(2.00-3.72)$ & $<.0001$ & $2.28(1.33-3.93)$ & .0028 \\
\hline $\begin{array}{l}\text { Days from admission to } \\
\text { surgery per } 1 \text {-d increase } \\
\text { when } \leq 5 \mathrm{~d}\end{array}$ & $1.07(1.01-1.14)$ & .0345 & $0.99(0.92-1.07)$ & .8687 & $1.19(1.08-1.31)$ & .0007 & $1.29(1.07-1.55)$ & .0064 \\
\hline $\begin{array}{l}\text { Days from admission to } \\
\text { surgery per } 1 \text {-d increase } \\
\text { when }>5 \text { d }\end{array}$ & $1.01(0.99-1.03)$ & .2368 & $1.07(1.05-1.10)$ & $<.0001$ & $1.06(1.03-1.08)$ & $<.0001$ & $1.04(1.01-1.07)$ & .0184 \\
\hline $\begin{array}{l}\text { Procedure time per 10-min } \\
\text { increase }\end{array}$ & $1.05(1.03-1.06)$ & $<.0001$ & & & $1.03(1.01-1.06)$ & .0022 & & \\
\hline
\end{tabular}

LOS, Length of stay; $O R$, odds ratio; $C I$, confidence interval; $B M I$, body mass index; $e G F R$, estimated glomerular filtration rate; $C O P D$, chronic obstructive pulmonary disease; $A S A$, American Society of Anesthesiologists; VATS, video-assisted thoracoscopic surgery. 
TABLE E4. Multivariable logistic regression of factors associated with postoperative events among patients receiving video-assisted thoracoscopic surgery

\begin{tabular}{|c|c|c|c|c|c|c|c|c|}
\hline \multirow[b]{2}{*}{ Risk factor } & \multicolumn{2}{|c|}{$\begin{array}{l}\text { Major morbidity } \\
\quad(n=4157)\end{array}$} & \multicolumn{2}{|c|}{$\begin{array}{c}\text { Discharge location } \\
\text { other than home }(n=4071)\end{array}$} & \multicolumn{2}{|c|}{$\begin{array}{c}\text { Postoperative } \\
\text { LOS }>19 \mathrm{~d}(\mathrm{n}=4147)\end{array}$} & \multicolumn{2}{|c|}{$\begin{array}{l}\text { Mortality } \\
(n=4157)\end{array}$} \\
\hline & $\begin{array}{c}\text { Adjusted } \\
\text { OR }(95 \% \text { CI })\end{array}$ & $P$ value & $\begin{array}{c}\text { Adjusted } \\
\text { OR }(95 \% \text { CI })\end{array}$ & $P$ value & $\begin{array}{c}\text { Adjusted } \\
\text { OR }(95 \% \text { CI })\end{array}$ & $P$ value & $\begin{array}{c}\text { Adjusted } \\
\text { OR }(95 \% \text { CI })\end{array}$ & $P$ value \\
\hline Age per 1-y increase & & & & & $0.99(0.98-1.00)$ & .0039 & $1.04(1.03-1.06)$ & $<.0001$ \\
\hline $\begin{array}{l}\text { Age per } 1 \text {-y increase when } \\
\text { age } \leq 40 \text { y }\end{array}$ & $0.97(0.95-0.99)$ & .0066 & $0.97(0.95-1.00)$ & .0325 & & & & \\
\hline $\begin{array}{l}\text { Age per } 1 \text {-y increase when } \\
\text { age }<40 \text { or } \leq 67\end{array}$ & $1.02(1.01-1.03)$ & .0002 & $1.04(1.03-1.05)$ & $<.0001$ & & & & \\
\hline $\begin{array}{l}\text { Age per 1-y increase when } \\
\text { age }>67 \mathrm{y}\end{array}$ & $0.98(0.97-1.00)$ & .0485 & $1.08(1.06-1.10)$ & $<.0001$ & & & & \\
\hline Female & $1.24(1.06-1.45)$ & .0067 & $1.18(0.99-1.41)$ & .0612 & & & & \\
\hline $\begin{array}{l}\text { BMI per } 1 \mathrm{~kg} / \mathrm{m}^{2} \text { increase } \\
\text { BMI per } 1 \mathrm{~kg} / \mathrm{m}^{2} \text { increase } \\
\text { when } \mathrm{BMI} \leq 27\end{array}$ & $0.96(0.94-0.99)$ & .0111 & $0.95(0.92-0.98)$ & .0010 & $0.95(0.91-0.99)$ & .0174 & $0.97(0.94-1.00)$ & .0490 \\
\hline $\begin{array}{l}\text { BMI per } 1 \mathrm{~kg} / \mathrm{m}^{2} \text { increase } \\
\quad \text { when } \mathrm{BMI} \geq 27\end{array}$ & $1.00(0.99-1.02)$ & .9378 & $1.02(1.00-1.04)$ & .0141 & $1.01(0.98-1.03)$ & .6451 & & \\
\hline Steroid & & & & & & & $1.91(1.07-3.40)$ & .0295 \\
\hline Congestive heart failure & $1.40(1.01-1.94)$ & .0458 & $1.92(1.34-2.73)$ & .0003 & & & $1.64(0.92-2.93)$ & .0926 \\
\hline Cerebrovascular disease & $1.34(1.01-1.79)$ & .0443 & $2.71(2.01-3.65)$ & $<.0001$ & & & & \\
\hline Diabetes & $1.32(1.10-1.58)$ & .0030 & $1.19(0.97-1.46)$ & .0959 & $1.55(1.19-2.02)$ & .0012 & & \\
\hline Dialysis & & & $1.78(1.09-2.91)$ & .0221 & & & $2.51(1.21-5.24)$ & .0139 \\
\hline eGFR $<60$ & $1.79(1.45-2.21)$ & $<.0001$ & $1.36(1.06-1.74)$ & .0146 & $2.21(1.66-2.95)$ & $<.0001$ & $1.96(1.23-3.14)$ & .0048 \\
\hline COPD & $1.26(1.03-1.53)$ & .0240 & $1.36(1.10-1.69)$ & .0052 & $1.54(1.15-2.06)$ & .0035 & $1.63(1.07-2.51)$ & .0242 \\
\hline $\begin{array}{l}\text { ASA risk class: III/IV/V/VI } \\
\text { vs I/II }\end{array}$ & $2.27(1.69-3.06)$ & $<.0001$ & $2.51(1.71-3.70)$ & $<.0001$ & $5.35(2.47-11.59)$ & $<.0001$ & —* & \\
\hline $\begin{array}{l}\text { Zubrod: in bed/bedridden/ } \\
\text { moribund vs normal } \\
\text { activity/fully ambulatory }\end{array}$ & $1.71(1.44-2.03)$ & $<.0001$ & $2.31(1.88-2.83)$ & $<.0001$ & $2.03(1.52-2.70)$ & $<.0001$ & $2.76(1.62-4.68)$ & .0002 \\
\hline $\begin{array}{l}\text { Days from admission to } \\
\text { surgery per } 1 \text {-d increase } \\
\text { when } \leq 5 \mathrm{~d}\end{array}$ & $0.98(0.93-1.04)$ & .5527 & $1.02(0.96-1.08)$ & .6020 & $1.02(0.94-1.11)$ & .6286 & $1.16(1.01-1.34)$ & .0371 \\
\hline $\begin{array}{l}\text { Days from admission to } \\
\text { surgery per } 1 \text {-d increase } \\
\text { when }>5 \mathrm{~d}\end{array}$ & $1.03(1.01-1.05)$ & .0017 & $1.07(1.05-1.09)$ & $<.0001$ & $1.09(1.06-1.11)$ & $<.0001$ & $1.00(0.95-1.04)$ & .9099 \\
\hline $\begin{array}{l}\text { Procedure time per 10-min } \\
\text { increase }\end{array}$ & $1.05(1.04-1.07)$ & $<.0001$ & & & $1.03(1.01-1.06)$ & .0036 & & \\
\hline
\end{tabular}

